\title{
Measuring Immigration Policies: Preliminary Evidence from IMPALA
}

\author{
Michel Beine / Brian Burgoon \\ Mary Crock / Justin Gest \\ Michael Hiscox / Patrick McGovern \\ Hillel Rapoport / Eiko Thielemann
}

CESIFO WORKING PAPER NO. 5109

CATEGORY 4: LABOUR MARKETS

DECEMBER 2014

An electronic version of the paper may be downloaded

- from the SSRN website:

- from the RePEc website:

- from the CESifo website:

WWW.SSRN.com

www.RePEc.org

www.CESifo-group.org/wp

\section{CESifo}




\title{
Measuring Immigration Policies: Preliminary Evidence from IMPALA
}

\begin{abstract}
This paper presents the methods and preliminary findings from IMPALA, a database that systematically measures the character and stringency of immigration policies. Based on a selection of data for six pilot countries between 1990 and 2008, we document the variation of immigration policies across countries and over time. We focus on three specific dimensions: the number of entry tracks for economic workers; the measurement and role of bilateral agreements that complement unilateral immigration policies; and aggregation procedures that allow for gauging the stringency of immigration regulations comparatively.
\end{abstract}

Keywords: immigration policies, stringency indexes, economic immigration, entry track.

\author{
Michel Beine \\ University of Luxembourg \\ michel.beine@uni.lu \\ Mary Crock \\ University of Sydney \\ mary.crock@sydney.edu.au \\ Michael Hiscox \\ Harvard University \\ hiscox@fas.harvard.edu \\ Hillel Rapoport \\ Paris School of Economics \\ hillel.rapoport@psemail.eu
}

\author{
Brian Burgoon \\ University of Amsterdam \\ B.M.Burgoon@uva.nl \\ Justin Gest \\ George Mason University \\ jgest@gmu.edu \\ Patrick McGovern \\ London School of Economics \\ p.mcgovern@lse.ac.uk \\ Eiko Thielemann \\ London School of Economics \\ e.thielemann@lse.ac.uk
}

\footnotetext{
Paper prepared for the CESifo Volume on “Migration policies”, November 2014.

We thank for useful comments and suggestions the participants of the CESifo Workshop on International Migration held in Munich on December 11-12, 2013. We are particularly grateful for useful feedback to Patricia Cortes, Tim Hatton, Anna-Maria Mayda, Francesc Ortega and Giovanni Peri as well as to two anonymous referees. All remaining errors are ours. We thank for useful research assistance Benedicte Souy and Diana Ingret as well as the coders of the IMPALA Consortium for providing detailed information on the entry tracks. Michel Beine gratefully acknowledges the financial support of the Fonds National de la Recherche du Luxembourg (contract FNR-CORE-C11/LM/1185166).
} 


\section{Introduction}

Understanding the character and stringency of immigration policies over time and space is crucial to debates about the causes, effects and governance of international migration. Alas, it is currently impossible to say much that is systematic about national immigration policies, about different regulatory aspects of, or changes in such policies. Despite many important measurement efforts, there are no comprehensive, cross-nationally comparable data on immigration policies and no established method for classifying, measuring, and comparing immigration laws and policies over countries and time. ${ }^{2}$ This is a major problem for applied research as it makes it extremely difficult to make precise and meaningful empirical claims about immigration regulations in a comparative or historical perspective.

The "International Migration Law and Policy Analysis" (IMPALA) database project addresses this issue by compiling a new database on immigration regulations with a particular focus on admissions policies. The project involves collaborative, interdisciplinary research to classify and measure the character of the major categories of immigration policy, including economic migration, family reunification, asylum and humanitarian migration, student migration, and acquisition of citizenship. Each country's laws and regulations are coded annually using a common standardized list of questions about the character of such regulations, with coding decisions based on transparently citing written laws and regulations. The resulting data provide comparable, valid and transparent measures of immigration regulation that captures the nuanced details of immigration law but also provides a basis to estimate the restrictiveness of such regulations at the level of the country, year, and particular aspect of migration and migration law. ${ }^{3}$

\footnotetext{
${ }^{2}$ While the term "immigration policy" generally refers to both policies of admission and integration, our project focuses largely on admission laws and regulations.

${ }^{3}$ See Gest et al. (2014) for an extensive discussion of these conceptual issues and the way they are addressed in the IMPALA project.
} 
The present paper provides an overview of the IMPALA database project and gives an empirical overview of immigration policies governing the admission of economic workers based on a snapshot from the first phase of the project. ${ }^{4}$ These data involve the coding of six sample countries between the years 1990 and 2008: Australia, France, Germany, Luxembourg, the Netherlands and the United States. This paper thus complements the information provided in Beine et al. (2015) which focuses on two specific years, namely 1999 and 2008 .

The discussion below focuses on immigration regulations with respect to economic migration. We document the evolution of entry tracks in policies governing economic migration. We interpret the total number of entry tracks that can be used as a raw indicator of the degree of complexity of that policy and the number of new tracks created each year as reflecting the extent of reforms in that area. We also provide some preliminary data collected in the context of bilateral agreements between countries. This category has been developed quite recently in the IMPALA project and we see it as of primary importance to capture the stringency of policies between pairs of countries, and a natural complement to the coding of unilateral policies. Finally, we discuss some challenges that the project is likely to face in the future, in particular with respect to aggregation.

The paper is organized as follows. Section 2 reviews the existing literature on immigration policy measurement. Section 3 presents the whole IMPALA project and clarifies some key concepts such as the concept of "entry track". Section 4 documents the evolution of entry tracks for economic migration for the six pilot countries. Section 5 discusses the coding of bilateral agreements. Section 6 discusses several aggregation issues and section 7 concludes.

\footnotetext{
${ }^{4}$ Our ultimate goal is to include the 26 OECD countries that are net-immigration countries over the period 19802008.
} 


\section{Existing Literature and Contribution of IMPALA}

The causes and consequences of admissions policies have given rise to important controversies.. Political economists have formulated competing theoretical approaches to explain actual v. desired immigration policies. Some scholars focus upon real or expected economic impacts of past immigration, such as fears about labor-market competition (Borjas 1999; Scheve and Slaughter 2001; Mayda 2006). Others emphasize ethnic tolerance or cosmopolitanism (Hainmueller and Hiscox 2010; Espenshade and Calhoun 1993; Citrin et al. 1997; McLaren 2001). Still others focus on cultural and ethnic differences or perceived threats to traditional culture and values, and a decline of "social capital" and trust, that can generate demands for more immigration restrictions (Putnam 2007; Huntington 2004; Dustmann and Preston 2007; Chandler and Tsai 2001; Burns and Gimpel 2000; Fetzer 2000, Harnoss 2014) or affect redistribution policies (see, e.g., Razin et al. 2011, Burgoon, 2014, and Alesina et al., 2014 for recent contributions). And some researchers posit that historical experience with diversity and colonialism foster familiarity with difference and make immigration more acceptable politically (Freeman 1979; Olzak 1992; Cornelius et al. 2004). In line with such reasoning, immigration policy may change with shifts in ideological climate, something that reflects also the domestic-political or organizational strength of extremist groups advocating intolerance (Kitschelt 1995; Joppke 1999; Givens and Luedtke 2004). Still others focus on immigrants' use of public welfare (e.g. unemployment insurance) and taxation, yielding fears from voters bearing fiscal burdens of immigration (Facchini and Mayda 2009; Hanson et al. 2007; Boeri et al. 2002).

A rapidly growing literature also explores the effects, not just the origins, of immigration policies. Demographers, economists, political scientists, and sociologists have all developed theories about such effects. A pressing issue in this scholarship is the extent to which policies affect the size and composition of migrant flows. It is already well established 
that migrant flows are determined by factors affecting the supply of different types of immigrants seeking to enter recipient countries. Such factors include network effects among migrants, and economic and political conditions in sending countries (e.g., Grogger and Hanson 2011). But immigration policies are also likely factors influencing migrant supply. Indeed, immigration policies directly affect the living and working conditions and the legal rights of immigrants, as well as the relations between immigrants and natives, thereby affecting immigrants' willingness to come. Recent scholarship has explored how particular admission rules and social-policy provisions influence immigrants' rights, labor-market incorporation and social position (Heath and Cheung 2007; Morrissens and Sainsbury 2005; Sainsbury 2006; Ruhs and Martin 2008; Ruhs 2011). For instance, Heath's analysis of the 'selectivity' of admissions policies and its implications for second-generation immigrants finds a greater likelihood of unemployment and a lower likelihood of upward social mobility for immigrants whose origins lie in guest worker-type programs in less selective countries (such as Austria, Belgium and Germany) (Heath 2007).

Given that immigration can affect the attitudes of natives and migrants with respect to economic insecurities and working practices (Burgoon and Raess 2011, Burgoon 2014), the effects of immigration policies likely extend to welfare states and other public goods. More broadly, immigration policies in general, and admissions policies in particular, may influence cultural and ethnic diversity, social capital, political participation, and partisan alignments (Putnam 2007; Bauer et al. 2000). Finally, legal researchers have highlighted the impact that immigration policies have on the human rights of migrants and on social cohesion (Bosniak 2006; Crock 2007; Dauvergne 2007; Rubenstein 2002).

A striking feature of this entire literature on the origins and consequences of immigration policies is that the often-voiced desire to make claims that hold across countries and over time far outstrips the literature's actual ability to do so. Despite some original and 
pioneering contributions, this emerging area of research is still hampered by the lack of valid, reliable and cross-nationally comparative data on immigration laws and policies.

For the most part, researchers comparing admissions policies have relied most commonly upon qualitative evidence from small $N$ studies that draw on a few countries (Watts 2002; Brochman and Hammar 1999; Hammar 1985; and Meyers 2004). However, an emerging strand of research has begun to develop quantitative measures of immigration policies in order to address important controversies about their historical development and persisting cross-national differences. Timmer and Williamson (1996; 1998), for instance, focus on broad measures of stringency in legislation in the late $19^{\text {th }}$ and early $20^{\text {th }}$ century; the Migration Integration Policy Index focuses on policies regulating integration (Niessen et al. 2007); Kogan (2007) examine "relative selectivity" surmised from immigration flows and their native counterparts; Mayda (2010) and Ortega and Peri (2009) gauge broad legislative reforms. The DEMIG project (http:/www.imi.ox.ac.um/projects/demig) conducted at the University of Oxford tracks immigration policies for economic migrants for a set of developed countries. Like Mayda (2010) and Ortega and Peri (2009), they identify the major immigration reforms.

Mayda (2010), Ortega and Peri (2009) and the DEMIG database provide good examples of measures of policies based on law changes. While they bring valuable information, this limits the comparability across countries since the levels of immigration restrictions are not known. In contrast, the main purpose of the entry-track approach is to capture these levels, from which reforms can be identified through a year-to-year comparison. Belot and Ederveen (2012) track cultural barriers to immigration; and Ruhs measures policies regulating the social rights of migrant workers (Ruhs 2011). Docquier et al. (2015) breakdown migration costs into a policy induced component and an incompressible one using the Galop survey. The policies are therefore estimated rather than directly observed using existing 
indicators. Other contributions have examined particular features of policy, including asylum and refugee policies, particularly in Europe (Thielemann 2003, 2004, 2006; Cerna 2008; Lowell 2005; Hatton 2004; Neumayer 2004; Czaika 2009), and citizenship policies (EUDO 2011; Howard 2005, 2006, 2009; Waldrauch and Hofinger 1997; Koopmans et al. 2005, 2010, 2012; Helbling 2008; Janoski 2010). These contributions generate valuable information on the countries that have implemented more or less restrictive admissions, integration, and citizenship regulations at particular points in time.

However, existing studies have important measurement limitations that hamper more systematic and comprehensive comparisons over time and space (see Gest et al., 2014, and Beine et al. 2015 for a fuller critique). ${ }^{6}$ First, most measurement efforts are quite compartmentalized in their focus - using disparate methodologies to examine laws for particular types of immigration, such as asylum, aspects of economic migration, border protection, etc. For instance, the MIPEX approach mainly focuses on integration policies. Another example is provided by Brücker et al. (2012) who review the immigration policies regulating the inflow of skilled immigrants in place in the major receiving countries. This clearly hinders comparison across admissions policies generally.

Second, most studies are very limited in their coverage with respect to space and/or time, focusing on small cross-sections of countries or on circumscribed and/or widely-spaced time periods. ${ }^{7}$ Third, many studies use coding methods that lack transparency and may suffer from unreliability or bias. The questions or aspects of regulations being coded in many measures tend to be highly aggregated, combining and smoothing-over many disparate features of regulation in ways that ignore crucial information (Coppedge et al. 2011). For

\footnotetext{
${ }^{6}$ For a list of the various attempts providing indices on immigration policies, as well as their main features, see Beine et al. (2015), and in particular the studies listed in Table 1. An assessment of the full set of existing studies is not possible given the space constraint. Nevertheless, we provide a number of illustrations of some weaknesses observed in the literature.

${ }^{7}$ For instance, Ortega and Peri (2009) use indices of immigration restrictiveness for 14 OECD countries observed for 6 different years. See also Docquier, Rapoport and Salomone (2012) for attempts to proxy various immigration policies in a bilateral setting.
} 
instance, some may mix de jure law with de facto implementation; others may conflate policy outputs with policy outcomes, while a few rely on categorizations that are themselves highly ambiguous and contentious, such as that of highly skilled immigrants (McGovern 2013). A related point is that, even within a given category of policy (e.g., economic immigration), the level and the evolution of immigration barriers significantly differ across sub-categories of prospective immigrants. Most of the exiting studies provide aggregated indices of immigration restrictions that hide the large variability of policies within a category. This motivates our approach to rely on the most disaggregated information in the immigration laws and to start from a central concept, namely, the concept of entry track.

Fourth and finally, the many possible combinations of aggregation and weighting across the component-questions that generate stringency indices is usually developed without transparent review, such as via expert survey, even though slightly different choices could yield much different outcomes and findings. All these problems undermine internal and external measurement validity and reliability. In short, the lack of comprehensive, crossnationally comparable data on immigration policies or systematic methods for gauging restrictions severely constrains scholarship and policy debates about the nature, origins and implications of immigration policies.

\section{The IMPALA Database Project}

The IMPALA database project seeks to develop and analyze precisely such comprehensive, comparable data on admissions policy and thereby promises to provide a foundation to address fundamental controversies about the nature, origins, and effects of immigration policies and laws. IMPALA compiles systematic, detailed information about 
immigration policy and laws that is comparable across countries, immigration issues, and time. $^{8}$

There are many different dimensions in a basic unit of observations of the IMPALA database: the year under investigation, the recipient country, the category of immigration policy, the specific entry track that is analyzed and the question applied to that entry track. ${ }^{9}$ Since the entry track concept is obviously a key dimension and characterizes the originality of the IMPALA approach, we explain hereafter the meaning of this concept. A given entry track corresponds to a specific way of entering the country. Such modes of entry are normally distinguished by the purpose of migration and by the characteristics of the participants. For example, one long-established track of entry is the H-1B Visa offered in the United States under the Immigration and Nationality Act of 1965 which allows employers to temporarily sponsor and employ foreign workers in specialty occupations.

The concept of entry track is similar to that of a visa but can be more or less inclusive depending on the similarities (or differences) in the ways in which countries treat various types of immigrants. The decision to create a separate entry track for a subset of prospective immigrants is made when a sufficient number of answers to the questions capturing the conditions of entry differ from those for an existing entry track, and that this track concern potentially a significant number of individuals. To illustrate, many countries admit seasonal workers, often through temporary migration programs. Some, such as France, Switzerland and the United Kingdom, have lumped all seasonal workers under one category of entry while others, including the United States, have created multiple tracks of entry that distinguish

\footnotetext{
${ }^{8}$ Given the large scale, interdisciplinary value, and diverse expertise needed to develop such information, the dataset is being developed by an ongoing and intensive collaboration between teams of economists, lawyers, sociologists and political scientists at five universities (co-PIs in parentheses): Harvard University (Michael Hiscox and Justin Gest); University of Luxembourg (Michel Beine and Hillel Rapoport); University of Sydney (Mary Crock); the University of Amsterdam (Brian Burgoon); and the London School of Economics and Political Science (Patrick McGovern and Eiko Thielemann).

${ }^{9}$ Note that as explained in section 5 , the bilateral dimension adds another dimension, namely, the country of origin.
} 
between agricultural and non-agricultural workers. We code these tracks separately when they are treated as such within national legislation.

The dataset focuses on formal and explicit immigration laws and regulations - de jure rules, not de facto implementation and case law. The coded laws and regulations include the most important categories of immigration entry, which we divide into distinct legal tracks clustered in five categories: (1) economic migration; (2) family reunification; (3) asylum and refugee immigration; (4) students; and (5) acquisition (and loss) of citizenship. The IMPALA consortium is also developing data on bilateral agreements between countries with respect to these migration tracks. ${ }^{10}$ Within these categories, the number of tracks varies substantially over time and across countries. Table 1 provides an overview of these categories and tracks from the data collected for the most recent period (2008 in most cases). The number of tracks per category ranges between 1 (Student category in Spain) and 64 tracks (Australian Economic category), and in a given year the number of tracks per country ranges between 40 and 143.

For any given track, coders examine national legislation, tracing statutes and regulations over time to identify rules for each year. Primary text legislation is checked against each country's annotated texts and electronic resources by legal scholars and professionals. Additional documentary sources include government department and agency publications, international conventions, reports from international organizations, and regional and bilateral agreements. Important in the latter are major bilateral agreements that confer preferential treatment upon migrants coming from a particular origin-country.

\footnotetext{
10 The IMPALA consortium has also begun coding undocumented, irregular migration and its control. The present overview will not report on these data.
} 
Table 1: Relevant IMPALA categories- most recent year

\begin{tabular}{|c|c|c|c|c|c|}
\hline & $\begin{array}{l}\text { Economic } \\
\text { migration }\end{array}$ & Family migration & $\begin{array}{l}\text { Humanitarian } \\
\text { migration }\end{array}$ & $\begin{array}{l}\text { Student } \\
\text { migration }\end{array}$ & Citizenship \\
\hline $\begin{array}{l}\text { Migration group } \\
\text { targeted }\end{array}$ & $\begin{array}{l}\text { Workers, } \\
\text { investors, } \\
\text { entrepreneurs }\end{array}$ & $\begin{array}{l}\text { Partners, children, } \\
\text { parents and } \\
\text { extended family } \\
\text { members }\end{array}$ & $\begin{array}{l}\text { Asylum seekers, } \\
\text { refugees, subsi- } \\
\text { diary protection, } \\
\text { temp.-prot., dom.- } \\
\text { violence, human- } \\
\text { traffic, medical } \\
\text { cases }\end{array}$ & $\begin{array}{l}\text { University, } \\
\text { school, vocational } \\
\text { and language } \\
\text { students }\end{array}$ & $\begin{array}{l}\text { All: Acquisition } \\
\text { and modes of loss } \\
\text { of naturalization }\end{array}$ \\
\hline $\begin{array}{l}\text { Tracks per country } \\
\text { (in 2008) }\end{array}$ & $15-64$ & $16-46$ & $6-43$ & $1-10$ & $13-28$ \\
\hline Questions per track & $\begin{array}{l}9 \text { country-level } \\
81 \text { track-based }\end{array}$ & 77 & $\begin{array}{l}116 \text { country-level } \\
186-220 \text { track- } \\
\text { based }\end{array}$ & 51 & $3-43$ \\
\hline
\end{tabular}


Using all such sources, coders identify the statutes and regulations that affect the number and types of immigrants that can enter a country, the conditions under which immigrants live and work, and their legal rights. In most cases, the questions and associated coding simply indicate the presence or absence of specific characteristics or restrictions (e.g., whether asylum seekers are detained while applications are pending). While the number of entry tracks is endogenous and is determined by the complexity of the law, the final set of questions is selected by coders in the pilot phase through an iterative process.

We first list all the characteristics and conditions addressed in the immigration regulations of the pilot countries (such as education requirements, age, etc.) and choose questions whose answers reflect these conditions. When one particular condition appears idiosyncratic (i.e., is found for only one country), we discard the questions concerning this condition. In other cases, the coding gathers non-binary quantitative data on variables such as number of admissions allowed each year for specific applicants, the duration of stay allowed, waiting periods, fees, and minimum and maximum fines and prison sentences for illegal activities involving undocumented immigrants.

A key feature of the IMPALA coding system is that questions vary by track and type of immigration, allowing later users of the data to construct track-specific measures best suited to their research questions. And fundamental to the IMPALA coding is that every decision about every coded question with respect to any given track, within any given country-year, refers to the original legal sources. The questions gauging distinct features of a given law can number in the hundreds for a given track and year. Table 2 provides a snapshot of the questions pertaining to economic migration for the sake of illustration.

This method is designed to make the database - unlike expert surveys and other attempts to reflect policy trends - completely transparent, replicable, and customizable by future researchers. The resulting data involves systematic cross-nationally and temporally 
comparable information on hundreds of features of law relevant to any given track within any given category of immigration. These features of the IMPALA methodology should help ensure that the coding of detailed provisions will provide reliable and valid measures of immigration law, policy, and regulation.

Table 2: Subsample of questions in the economic migration category

\begin{tabular}{|l|l|}
\hline 1 & Does the employer need to operate a labour market availability test for this entry track? \\
\hline 2 & Does the country adopt a labour shortages test for this entry track? \\
\hline $\mathbf{3}$ & If yes, does the country have a policy of listing shortage occupations for suitably qualified immigrants? \\
\hline 5 & If age considered? \\
\hline 6 & If yes, what is the maximum age? \\
\hline 7 & Is proficiency in official language(s) of receiving country considered, as defined by selecting country? \\
\hline 8 & Must applicants show evidence of proficiency in the official language(s) of the receiving country? \\
\hline 9 & Is a compulsory language knowledge test required? \\
\hline 10 & Are educational qualifications from the country of origin considered? \\
\hline 11 & Are educational qualifications from the receiving country considered? \\
\hline 12 & If specified, what is the minimum level of education expected (CASMIN educational classification)? \\
\hline 13 & Are training qualifications obtained outside of the receiving country considered? \\
\hline 14 & Are training qualifications obtained inside of the receiving country considered? \\
\hline
\end{tabular}

As an initial offering, we shall provide some illustrative examples of the possible measures of restrictiveness or stringency in admissions policies. One straightforward method involves scaling answers to questions relevant to stringency as taking-on higher values for higher stringency. For instance, the binary yes-no questions are, where relevant to restrictiveness, scaled as 1 for higher stringency and 0 for less. ${ }^{12}$ The simplest measure of stringency, to be discussed below, is the sum of the values in a given track-country-year ignoring binary questions whose implications for stringency are less obvious, ignoring also

\footnotetext{
${ }^{12}$ Some questions are coded "required" ( 1 for higher stringency), "considered" ( 0.5 for higher stringency), and "no" ( 0 for less stringency). Finally, some questions involve permits coded on a 4-point scale: permanent permit (-1 least stringent), probationary permanent permit (-0.5 less stringency), temporary permit with the prospect of being eligible to apply for transition to a related permanent permit ( 0.5 stringency), and temporary permit without being eligible to apply for transition to a related permanent permit (1 stringency).
} 
non-binary quantitative or qualitative information, and not weighting aspects of law relevant to stringency. Such an approach is only the simplest and certainly not the most accurate method of aggregation and weighting. Indeed, the IMPALA project is developing various algorithms for such aggregation and weighting. Seeing even the simplest aggregation, however, clarifies how the IMPALA data can be leveraged to systematically measure restrictiveness and bias in policies. The combination of nuanced raw data, and methods of gauging stringency and bias, allow the IMPALA database project to address countless controversies about immigration, including those discussed above.

The planned national coverage of the IMPALA database encompasses all economies in the Organization of Economic Cooperation and Development (OECD), except those with negative net immigration (i.e., net positive emigration) over the past two decades. This leaves 26 countries: Australia, Austria, Belgium, Canada, Czech Republic, Denmark, Finland, France, Germany, Greece, Hungary, Iceland, Ireland, Italy, Japan, Luxembourg, the Netherlands, New Zealand, Norway, Portugal, Slovakia, Spain, Sweden, Switzerland, the United Kingdom, and the United States. These countries receive the bulk of international migrants and include the five countries receiving the most immigrants over the past 50 years: the United States, Canada, Australia, the United Kingdom, France, and Germany.

To illustrate the importance of our countries selection, Figures 1 and 2 provide the proportion of total and skilled immigration for each country considered in the IMPALA project. The data refers to the last version of the Docquier and Marfouk (2006) database providing bilateral migration stocks by education level. ${ }^{13}$ Figure 1 gives the proportion of immigrants in total world immigration in each destination country considered the IMPALA project.

\footnotetext{
${ }^{13}$ See Artuc et al. (2015). This dataset provides the bilateral stocks for three education levels for all countries of origin (203 countries) and most destinations (194 countries). The initial version included only 30 destinations. We use the last available period of time, that is, the year 2000.
} 
The IMPALA countries represent about half of the total immigration around the world (about 110 million registered migrants in 2000 in the dataset). While this seems rather small, one has to take into account that what matters also is the importance of immigration in the total population of the receiving country. Furthermore, the definition of migrants used here (foreign born residents) leads in some cases to a strong underestimation of the economic importance of immigration. ${ }^{14}$ Finally, recall that the figures exclude immigrants who were younger than 25 at the time of the census or survey, as well as illegal immigrants.

Interestingly, our selection of countries captures about 70 percent of the global immigration of skilled workers. This is important because the project aims at capturing not only the restrictiveness (or stringency) of policies in terms of global immigration, but also their selectivity. The shares in Figure 2 illustrate the important role played by the traditional English speaking countries (US, UK, Australia and Canada) in attracting educated workers. The data also illustrate that continental European countries such as Germany and France tend to attract a higher proportion of unskilled workers compared to English speaking countries. The project aims at shedding more light on the role that admissions policies play in generating such outcome.

In addition, the IMPALA project will code European Union supranational regulations parallel to the national laws of member states. Such cross-national and EU coverage provides substantial leverage to examine the core theoretical questions discussed above, as the countries exhibit widely varied economic, social, and institutional settings. While the consortium intends to code all years between 1960 and the present, we prioritize coding between 1980 and 2008, since documentation for earlier years tends to be incomplete.

\footnotetext{
${ }^{14}$ For example, Luxembourg has the highest proportion of foreigners in the total labor force, with more or less $60 \%$ of workers coming from abroad. Furthermore, the figures provided here do not account for cross-border workers coming from neighboring countries, which represent approximately $25 \%$ of the total labor force in Luxembourg.
} 
Figure 1: Proportion of immigration in each IMPALA country, stocks, year 2000.

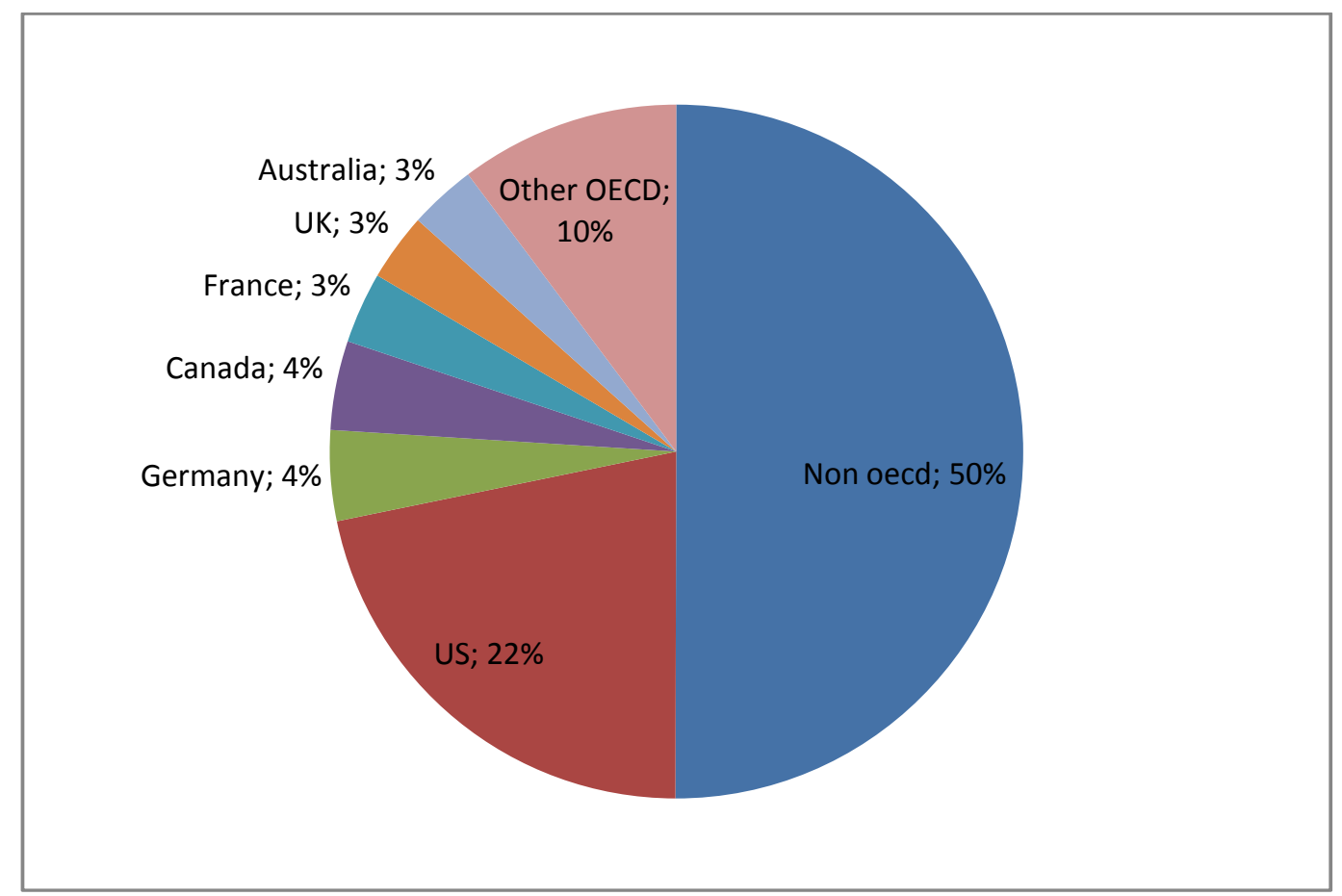

Source: Docquier-Marfouk (2006) and own calculations. 
Figure 2: Proportion of skilled immigration in each IMPALA country, stocks, 2000.

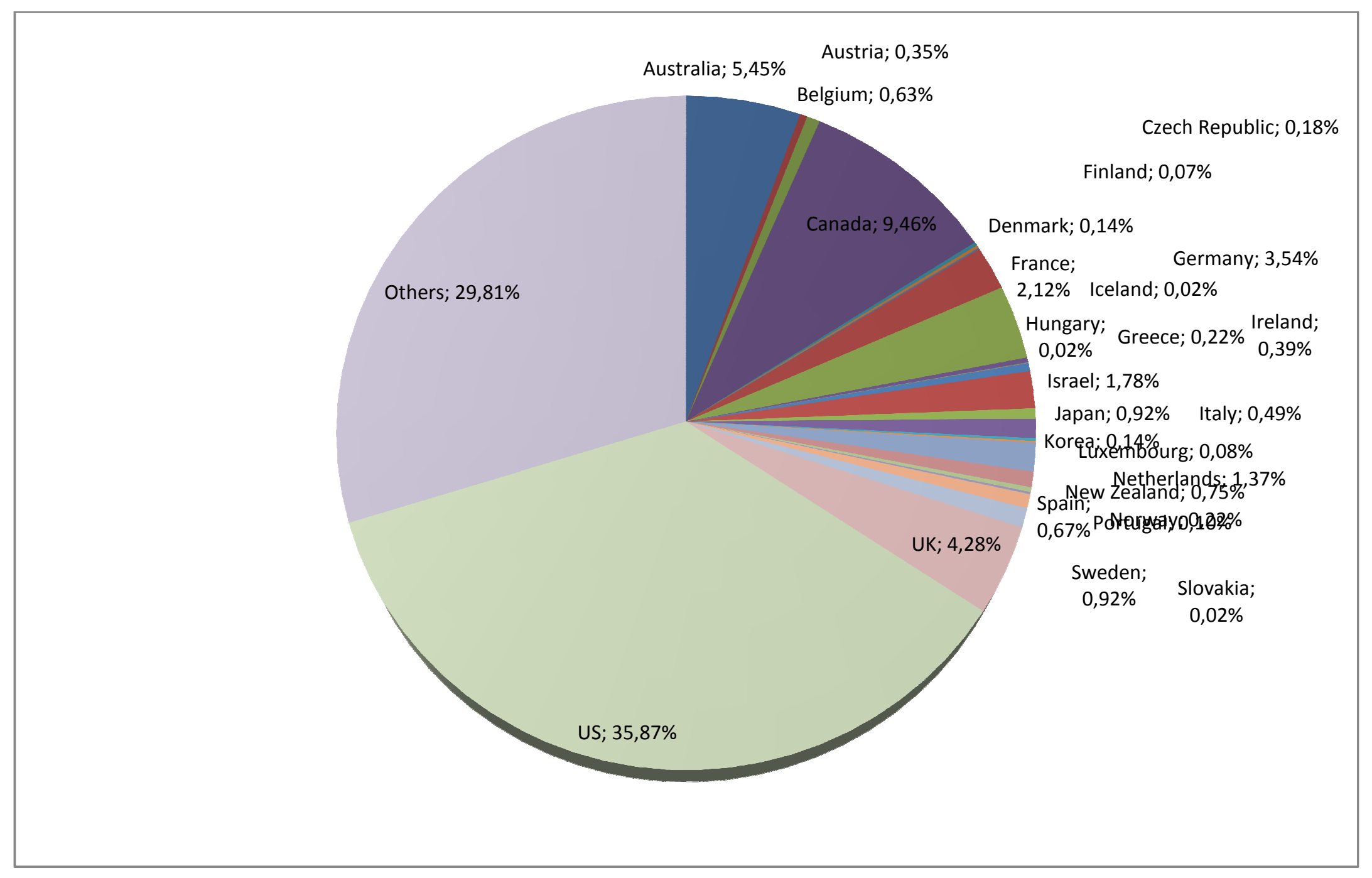

Source: Docquier-Marfouk (2006) and own calculations. 
At the time of this writing, we have completed the initial pilot study phase of the IMPALA project. This phase involved the development and synchronization of tracks, questions and coding, and the development of methods of international, inter-coder storage, communication and dissemination of coded laws and regulations. The first phase of coding has focused on economic, family, student, and humanitarian migration in Australia, France, Germany, Luxembourg, the Netherlands, Spain, Switzerland, the United Kingdom and the United States, and the years between 1999 and 2008. In the coming year we hope to complete and make available the coding for these pilot countries, years, and tracks, and will continue expanding the database, depending on funding constraints.

\section{Evidence from early estimates}

\subsection{Number of tracks}

The number of entry tracks can be used as a raw estimate of the evolution of admission policies in terms of complexity. The multiplicity of these entry tracks show that countries fine tune their policies in order to target some specific categories of migrants. This is obviously the case for economic migration on which we focus in this section.

It should be mentioned that the mere number of entry tracks is not per se a perfect indicator of the stringency or selectivity of immigration policies. Different entry tracks might imply fairly similar conditions of entry and fairly similar selection criteria. Nevertheless, it might be expected that countries with more entry tracks tend to have more restrictive/selective immigration policies. Also, it is not obvious from the figures that the number of entry tracks is correlated with the absolute or the relative size of the immigrant population. For instance, Australia displays an important stock of skilled immigrants -both in absolute terms $(1638000$ in 2001) and in relative terms (43.7\% of the corresponding native population in 2001) - as well as a large number of entry tracks. Nevertheless, the very low number of entry tracks for 
the US (which is by far the most important receiving country with corresponding numbers of more than ten millions and $11.27 \%$ respectively) suggests that the correlation is not obvious. Germany had after 2005 more entry tracks than the US, while it receives ten times less skilled immigrants compared to the US.

A second word of caution concerns entry tracks of secondary importance. Entry-tracks such as religious workers, news correspondents, or airport staff might be important from a societal point of view but concern relatively few workers. In general, the importance of entry tracks in the global immigration policy of a country might be assessed by matching immigration flow data at the entry track level with the data collected in the IMPALA project. Such flow data are not yet available and their collection is definitely an important avenue of investigation.

Figure 3 presents the number of entry tracks for economic migration for the 6 pilot countries for which we have this information: Australia, France, Germany, Luxembourg, the Netherlands and the US. The period covered is 1990-2008 and we present the annual evolution. The comparison of the number of entry tracks across countries for a given time period gives an idea of the relative degree of complexity of the immigration systems regarding economic migrants. The evolution over time of the total number of entry tracks within a country might be used as an indicator of policy changes. Nevertheless, the number of new tracks might be a better indicator of reforms, as discussed in the next subsection. 


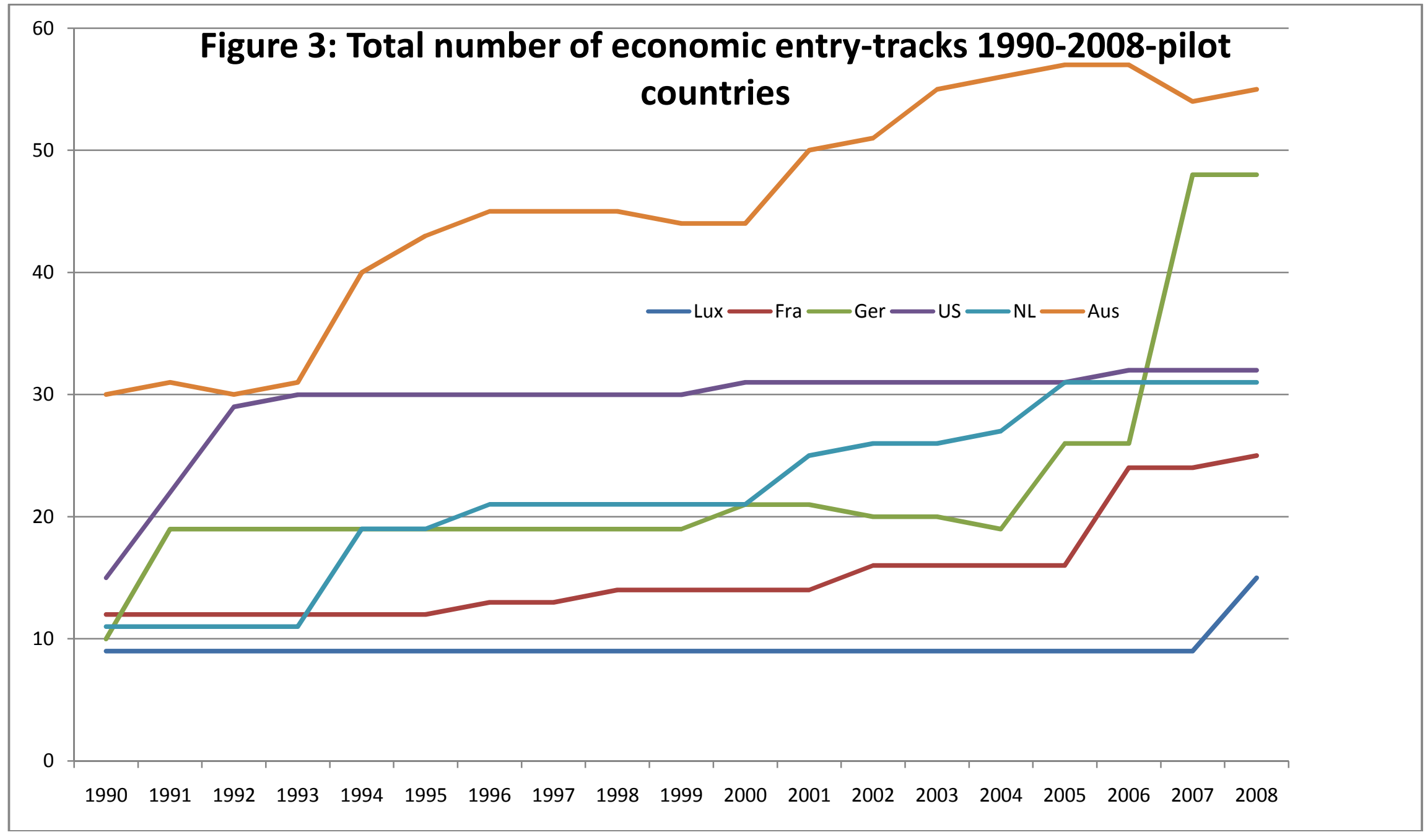


Figure 3 shows that by far, Australia exhibits the most detailed and complex immigration policy within our sample of pilot countries. In 2008, Australia had 55 different entry tracks for economic migration only. It is almost double the number of entry tracks for the US (31 in 2008), a number that has stayed quite stable since the last major immigration reform of 1992-1993. Figure 3, shows that in general, European countries tend to have fewer modes of entry for economic migrants. Nevertheless, this has recently changed in some countries such as Germany or France, which conducted important reforms of their immigration policies. Another case is Luxembourg, which adapted its immigration system to the European directives in this matter.

The evolution over time of the number of tracks suggests that in general, immigration policies tend to become more complex. A comparison of the number of tracks observed in 1999 and 2008 reveals that all countries have increased the number of their entry tracks. This trend is not restricted to economic migration but also to the admission of students or relatives admitted under family reunification procedures (see Beine et al. 2015).

\subsection{New tracks}

It might be interesting to look at the evolution of entry tracks over time. The net variation in the total number is driven by the creation of new tracks and by the suppression of entry tracks that the authorities consider inefficient or outdated. Therefore, the creation of new tracks might be used as an indicator of immigration reforms in each country. The panels in Figure 4 give the number of new tracks created each year in the six countries under consideration. The height of the bars can be used to visualize the extent of immigration reforms and their timing. Once again, we focus on the new tracks governing the entry of economic migrants.

The important reforms to immigration policy in France in 2006 ("immigration choisie", or "chosen immigration") can be easily seen from the first panel. The same can be 
said for the Netherlands (reform in 1994), for Luxembourg (reform in 2008) and for Germany (reform in 2007). For Luxembourg, the reform in 2008 has taken the form of a full adaptation of immigration laws to the directives of the European Union. Before this major reform, the regulation governing economic immigration was left unchanged for more than 20 years. The 2008 reform increased the selection of economic migrants in terms of skills. For instance, for migrants coming from outside the European Union, the new system makes a distinction between highly qualified workers, salaried workers, seasonal workers, intra-corporate transferees, researchers, and sportspersons. Before 2008, all these categories were embedded in three work permits (A, B and C) that were different only in terms of the length of the permit. The 2008 reform might therefore be seen as a clear move towards a more selective policy for economic migrants. The same trend is observed in other European continental countries such as France and Germany, although the changes there were less dramatic. For instance, France in 2006 created new tracks for scientists coming from outside Europe as well as special visas for skilled workers (e.g., the "Skills and Talents visa").

The panel related to the US entry tracks reveals that since 1992, immigration policy in the US has not experienced any significant reform. Finally, it should be emphasized that Australia has been by far the most active country in terms of immigration policy. Over the period of investigation, Australia has created at least one new way of selecting economic migrants each year. The diversity of the new tracks is also quite stunning. For instance, Australia created an additional visa to the existing one in terms of holiday working permit in 2002. Australia created a new State-sponsored visa for investors in 2003, extending the existing system for business owners. These examples illustrate that the complex system of immigration regulation in place in Australia is the outcome of regular additions by the authorities over time. 

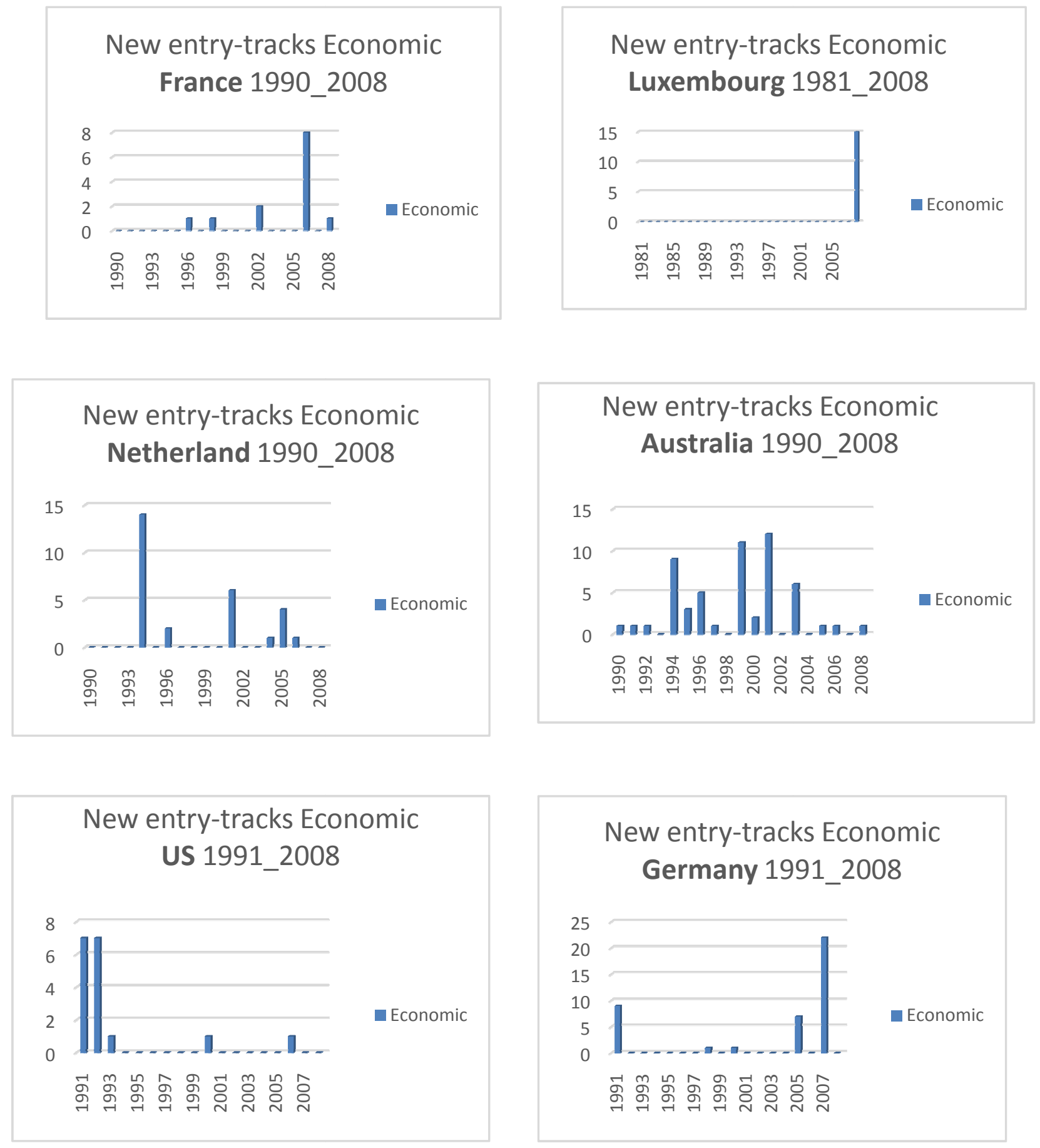

Figure 4: New economic entry-tracks for pilot countries 1991-2008 


\section{The bilateral dimension}

\subsection{Motivation}

The IMPALA project includes an expert group working on bilateral issues. Its objective is to complement the above information on (unilateral) admissions laws and policies (that is, general policies that apply indistinctively to all countries) with information from bilateral (and multilateral) agreements at the level of country pairs (e.g., US-Canada) or of groups of countries (e.g., on intra-EU mobility). At the most general level, bilateral agreements may be seen as deviations from global policies; conceptually this could be in both directions in terms of restrictiveness but in practice most bilateral agreements introduce waivers on existing constraints.

Information on bilateral agreements in the field of immigration policy can be found from multiple national and international sources. National sources include registers of all bilateral agreements for single countries such as the UK, USA or Australia. ${ }^{17}$ International sources include comparative datasets on bilateral agreements from organizations such as the United Nations, ${ }^{18}$ the OECD (2004) and the International Organization for Migration. ${ }^{19}$ In addition, the European Union publishes comparative data on bilateral agreements in general ${ }^{20}$ as well as specific multilateral agreements in the field of immigration between the EU and certain groups of sending countries. ${ }^{21}$

Bilateral agreements allow for capturing additional dimensions of admissions policies. Information from bilateral agreements can either cover certain aspects not included in the IMPALA categories described aboveor relate to these categories but allow for refining the

\footnotetext{
$17 \quad$ See, respectively: http://www.fco.gov.uk/en/publications-and-documents/treaties/treatylinks, http://www.state.gov/s/l/treaty/tif/index.htm, and http://www.info.dfat.gov.au/treaties/

${ }^{18}$ See http://treaties.un.org/Pages/DB.aspx?path=DB/MTDSG/page1_fr.xml

${ }_{10}$ www.imldb.iom.int/changeSearchType.do?searchType=advanced\&classDescription=RegionalInstruments

${ }_{20}$ http://ec.europa.eu/world/agreements/default.home.do

${ }_{21}$ See for example the database on all bilateral agreements linked to readmissions concluded by the Maghreb countries and the EU Member States since the 1950s: http://www.mirem.eu/datasets/agreements/index
} 
way policy indices could be constructed. In this latter case, the bilateral information can be used to refine the analysis in two ways. First, bilateral agreements can be used to compute bilateral (not just aggregated) scores of, say, restrictiveness or selectivity of immigration policies and, in turn, this can be used for bilateral analysis (e.g., to assess the role of immigration policies on bilateral migration flows) - see below. Second, even if one uses an "aggregate" rationale, information from bilateral agreements can be used to re-compute aggregate IMPALA scores/indices for each individual country, using for example weighted averages of bilateral scores.

In the next sub-sections, we show why it is important to account for this bilateral dimension when examining the determinants of migration between two countries, as well as for purposes of aggregation.

\subsection{Example 1: a bilateral (gravity) setting}

Let us assume, for example, that our goal is to understand the determinants of immigration between two countries. Typically, bilateral migration flows (their size, skill or gender composition, etc.) are analyzed in a framework that economists and regional scientists refer to as the gravity framework, that is, a framework where sending and receiving countries are seen as two planets, each with its own characteristics captured by a country fixed effect, while gravity forces (the distance between countries, their wage or educational differential, the fact that they share a common border/language, and their mutual accessibility - which can be the result of bilateral agreements) explain the bidirectional flows of goods (trade), capital and people (migration).

Economists supplement this framework with micro-foundations in the sense that they model the individual decisions of firms to export, or of people to migrate, as resulting from an optimization procedure. In the field of migration, this takes the form of so-called "pseudo 
gravity models" (see among many others Beine and Parsons, 2012, Bertoli and FernandezHuertas Moraga, 2013, or Bertoli and Rapoport, 2015, for recent applications) of the type:

$$
\ln \left(\frac{m_{i j, t}}{N_{i i, t}}\right)=\alpha \ln \left(\frac{w_{j, t}}{w_{i, t}}\right)+\beta \operatorname{MigPol}_{i, t}+\delta \ln \left(\operatorname{dist}_{i j}\right)+\theta M_{i j, t}+\mu_{i j, t}+\varepsilon_{i j, t}
$$

where the dependent variable is the ratio of $m_{i j, t}$, the number of migrants from sending country $I$ to receiving country $j$, to $N_{i i, t}$, the population of country $i$ at time $t$. Hence, the dependent variable gives the number of migrants from $I$ to $j$ expressed as a proportion of the sending country population (i.e., this is an emigration rate). The usual explanatory variables are the wage differential between the two countries, $\frac{w_{j, t}}{w_{i, t}}$, the distance between them, dist $t_{i j}$ (note that distance could be geographic but also cultural, linguistic, etc.), and the immigration (or diaspora) network of immigrants from country $i$ in country $j$ in the previous period, $M_{i j, t}$, which has been shown to significantly affect the size, skill and gender composition of immigration (see McKenzie and Rapoport, 2007 and 2010, Beine, Docquier and Ozden, 2011a and 2011b, Beine and Salomone, 2013).

Regarding immigration policy, its global (or unilateral) dimension can either be considered as accounted for by the receiving country (or country-year) fixed effect, or singled out through a specific, time-varying indicator, $\mathrm{MigPol}_{i, t}$. Finally, $\mu_{i j, t}$ captures unobserved or omitted factors such as bilateral migration policies; note that networks $M_{i, j t}$ may be strongly correlated with bilateral migration policies while the dependent variable itself, $m_{i t, j}$, will most directly be affected by bilateral agreements; in addition, the existence of bilateral immigration agreements is likely affected by whether the two countries share the same language, have a historical colonial link, etc. Hence, failure to include measures of bilateral immigration policies will lead to biased estimates of virtually all the coefficients in the above equation. 


\subsection{Example 2: aggregate indices of immigration policy stringency}

As just explained, the information contained in bilateral agreements allows for computing bilateral measures of admissions policy that can be used for bilateral (gravity) analysis of immigration flows. In addition, the bilateral information that can be matched with the IMPALA categories can further be used to re-compute aggregate IMPALA score/indices of the stringency of immigration policies in each country (using simple or weighted averages of bilateral scores) which can in turn be used for aggregate (cross-country) analysis.

To illustrate this point, let us look at Figure 5. Figure 5 assumes two receiving countries, A and B (say, France and Belgium) potentially receiving immigrants from the other country as well as from two emigration-only countries, C and D (say, Congo and Morocco). Immigration policies in countries $\mathrm{A}$ and $\mathrm{B}$ have two dimensions: restrictiveness (quantitative restrictions on immigration), denoted by $\mathrm{R}$, and selectivity (qualitative restrictions), denoted by S. In the IMPALA project we code "one" if the immigration law of the country has quantitative (respectively, qualitative) restrictions, and "zero" otherwise.

Assume that country $A$ is both restrictive $(R=1)$ and selective $(S=1)$, that is, has immigration laws imposing quantitative and qualitative restrictions on immigration, while country $B$ is restrictive $(R=1)$ but not selective $(S=0)$. If we compare countries $A$ and $B$, we will conclude that they are equally restrictive while country $\mathrm{A}$ is more selective. If we compare according to an aggregate index, for example an "aggregate IMPALA score" summing the " $1 \mathrm{~s}$ " for the different dimensions of immigration policy (IMPALA score=R+S), then country A has a score of 2 and country B a score of 1 . We will therefore conclude that country A has a more stringent immigration policy than country B or, in other words, that it is less open to immigration. 


\section{Figure 5: Why is it important to take bilateral agreements into account?}

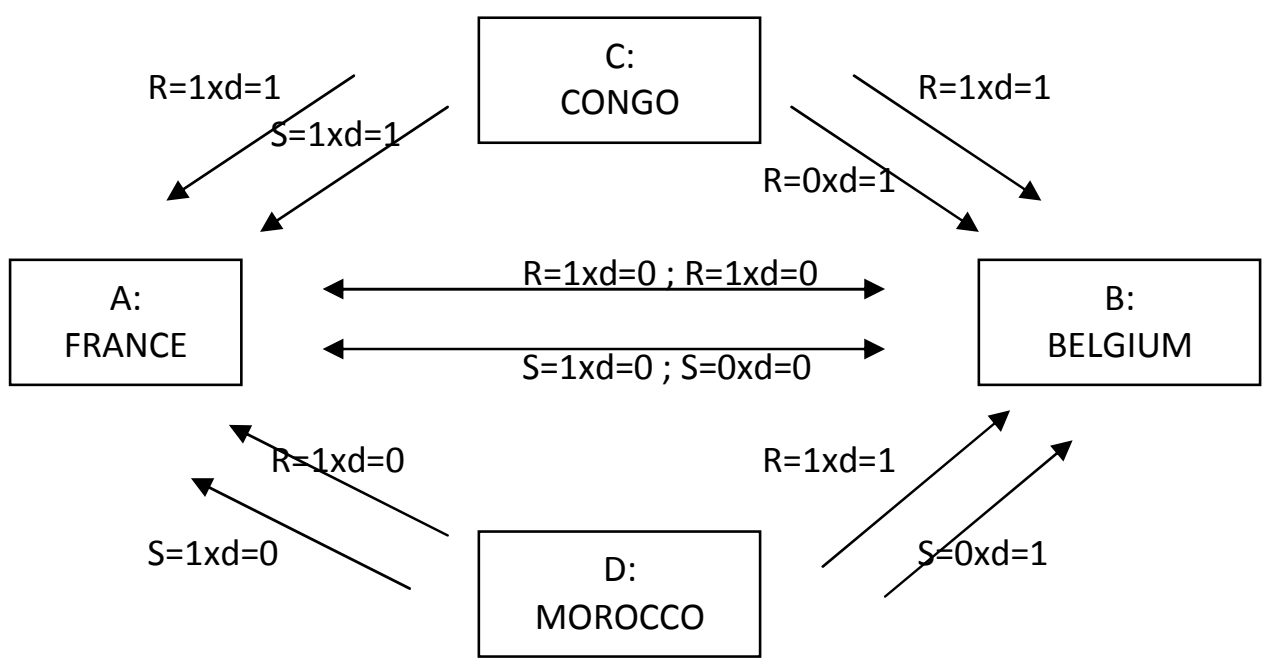

Note : $\mathrm{R}=1$ stands for restrictive immigration policy. $\mathrm{S}=1$ stands for selective immigration policy.

Let us now capture the bilateral dimension. For all origin countries we draw two arrows from that country to each potential destination, with the direction of the arrow pointing to the direction of the immigration flow: one for whether the immigration flow is subject to a quantitative restriction (the upper arrow), and one for whether it is subject to a qualitative restriction (the lower arrow). Given what we know on general immigration policies in countries $\mathrm{A}$ and $\mathrm{B}$, for all arrows toward $\mathrm{A}$ we write "1" next to each R-arrow and next to each S-arrow, and for all arrows toward B, we write "1" next to each R-arrow and "0" next to each S-arrow. We then multiply each number by a dummy taking the value 0 or 1 depending on whether there exists a bilateral agreement waiving the restriction $(\mathrm{d}=0)$ or the general restriction considered applies $(\mathrm{d}=1)$.

Assume that country A signs a bilateral agreement with country D whereby any restriction on immigration from $\mathrm{D}$ to $\mathrm{A}$, be it quantitative or qualitative, is waived. The dummy variable capturing the existence of a bilateral agreement therefore takes the value "0" for both arrows from D to A. Given that no such agreement exists between A and C, the 
dummy variable capturing the (non-)existence of a bilateral agreement between A and D takes the value " $1 "$ for both arrows.

Assume also that A and B are members of a multilateral agreement (e.g., the European Union) establishing free mobility of people between its members. That is, any restriction to mobility between them, be it quantitative or qualitative, is cancelled by virtue of the joint membership in the multilateral organization. Multilateral agreements can be treated as a series of reciprocal bilateral agreements. To capture this, we multiply all R and S scores by "0", as shown for the bidirectional arrows between A and B. Finally, we assume that country B has no bilateral agreement with the other, third countries. The dummy variable capturing the (non)existence of a bilateral agreement between $\mathrm{B}$ and, respectively, $\mathrm{C}$ and $\mathrm{D}$, takes the value "1" for all four remaining arrows.

We are now able to compare immigration policies across countries in a more meaningful way. To illustrate this, let us have a look at Table 3. Table 3 shows that while country A is both restrictive and selective, its restrictions apply only in the case of country D. If we give equal weight to all origin countries (of course, different weighting procedures can be applied depending on the choices that will be made to compute IMPALA indices) ${ }^{22}$ then country A has a restrictiveness score of $1 / 3$ and a selectivity score of $1 / 3$, which aggregate to an overall average score of $2 / 3$. Country $B$, on the other hand, is restrictive but not selective. However, quantitative restrictions apply to two countries out of three. Using the same weighting procedure as above, country $B$ therefore has a restrictiveness score of $2 / 3$ and a selectivity score of 0 , which aggregate to an overall score of $2 / 3$. Comparing A and B, we will now conclude that $\mathrm{A}$ is less restrictive (and still more selective, although by a lower margin) than B, while the two countries have the same level of openness in their overall immigration

\footnotetext{
${ }^{22}$ For example, weights could be assigned according to country size, or to the size of immigration flows. In any event, the IMPALA consortium proposes to turn the raw data over to researchers who can make their own choices, including about bilateral weights.
} 
policy. This is a very different - and much more accurate - conclusion from the one we reached when looking at "unilateral" immigration laws only.

Table 3: Capturing the bilateral dimension of immigration policies - an example

\begin{tabular}{|c|c|c|c|c|c|}
\hline \multicolumn{3}{|c|}{ Country A (France) } & \multicolumn{3}{c|}{ Country B (Belgium) } \\
\hline General & $\mathbf{R = 1}$ & $\mathbf{S}=\mathbf{1}$ & General & $\mathbf{R = 1}$ & $\mathbf{S = 0}$ \\
\hline B & 0 & 0 & A & 0 & 0 \\
\hline C & 0 & 0 & C & 1 & 0 \\
\hline D & 1 & 1 & D & 1 & 0 \\
\hline Average & $\mathbf{R}=\mathbf{1 / 3}$ & $\mathbf{S}=\mathbf{1 / 3}$ & Average & $\mathbf{R = 2 / 3}$ & $\mathbf{S}=\mathbf{0}$ \\
\hline
\end{tabular}

As is clear from the above, our treatment of bilateral agreements within the IMPALA framework is essentially to see them as a discrimination (or privilege) favoring some particular countries for which an existing restriction that applies unilaterally to other countries is waived. Formally, we code bilateral agreements as a dummy variable taking the value "0" when a particular restriction is waived for a particular country and "1" otherwise. Following the general principles of the broader project, this will be very transparent in our coding of the data, allowing users to make their own aggregation choices. The same logic applies to multilateral agreements, such as those among EU countries, as they can be seen as a series of bilateral agreements.

As a "real-world" illustration of such a mechanism, we can use the case of bilateral agreements concluded by Germany with a set of extra-European countries. We focus here on the regulations governing the movement of one particular type of workers, namely intracorporate transfers (ICTs). This is therefore specific to a particular entry track. With the prevailing global trend towards a higher degree of internationalization of economic activities, this particular entry track has become more important over time. Actually, the EU promoted ICTs through the adoption of the European Directive on ICTs in May $2014 .{ }^{24}$ Germany, on

\footnotetext{
${ }^{24}$ http://eur-lex.europa.eu/legal-content/EN/ALL/?uri=uriserv:OJ.L_.2014.157.01.0001.01.ENG.PE-CO_S 58/14
} 
the other hand, had already concluded many agreements with the US to facilitate the access of employees of multinational companies to their subsidiaries in Germany.

The provisions governing the entry of ICTs are included in more general bilateral agreements, called "Partnership and Cooperation Agreement", "Euro-Mediterranean Agreement" or "Stabilization and Association Agreement". ${ }^{26}$ These agreements involve bilateral cooperation in other areas than immigration, such as trade agreements. As of 2008, Germany had signed 23 regulatory agreements on ICTs since 1960, with only 14 bilateral agreements (BAs) still in application today. In particular, as an EU Member State, Germany concluded agreements on regulation of entry of ICTs with Ukraine, Russia, Moldova, Kazakhstan, the Kyrgyz Republic, Azerbaijan, Armenia, Georgia, Uzbekistan, Jordan, Macedonia, Croatia, Algeria and Tajikistan.

The general immigration law in Germany stipulates that the maximum stay of ICTs without being subject to a labor market test is 3 years. ICTs coming to Germany under the specific BAs are subject to a different regulation. They can stay up to 4 years without any labor market test. ${ }^{27}$ Therefore, this provision might be seen as relaxing the restriction associated to the general immigration regulation. This is nevertheless subject to the fact that the employee has been employed for at least one year before the transfer to the German branch. Furthermore, if the maximum period of stay of 4 years is reached, the ICT is allowed to reapply for a maximum of 2 years. This illustrates that BAs can introduce variations in the degree of stringency for specific entry tracks in both directions, i.e. may release some of the restrictions but at the same time impose other ones than those prevailing in the general immigration law.

\footnotetext{
${ }^{26} \mathrm{http}: / / \mathrm{www} 1 . \mathrm{bgbl}$.de/

27 See http://www1.bgbl.de/ and in particular ASAV, Art. 3 para 3 juncto Beschv, 28 para.2
} 


\section{Aggregation issues}

The most disaggregated unit of observation in the IMPALA database takes the form of the answer to a specific question applying to a particular entry track in a specific migration category at a single point of time in any given country of immigration. In other terms, the basic observation has a fivefold dimension: question/track/category/time/country. The questions can take different forms: a dummy variable (0/1) capturing some qualitative information and some continuous variable capturing some quantitative information. Two examples can illustrate this four-dimensional type of information. The French reforms of 2006 created a new track 'Skills and Talents' in the economic migration category. The answer to the specific question 'Is there a requirement of education qualification/degree?' takes the value of 1, reflecting a positive answer. As a second example, still in France, in 2008, a new track for Investors and Entrepreneurs 'Exceptional Contribution to French economy' was created. In order to qualify and to have the visa granted, the applicants need to invest a minimum amount of 10 million Euros in the French economy.

One of the ultimate objectives of the IMPALA database is to create indexes capturing the characteristics of immigration policy. These might be restrictiveness indexes for instance, capturing the extent to which a given country sets tough conditions to allow prospective migrants to enter the country. In turn, this raises the question about how to aggregate the basic information collected in the IMPALA database. We disregard here the issue of aggregation across categories (economic, family, students) and focus only on aggregation within a single country. We address here two types of aggregation: (1) aggregation of the questions within a given track, and (2) aggregation of entry tracks within a given category. 


\subsection{Aggregation of questions}

Several important issues emerge regarding the aggregation of questions within a single entry track. A first issue relates to the combination of quantitative and qualitative information. For instance, the requirement of a minimum wage to qualify as a highly skilled worker relates not only to whether this requirement exists but also to the amount that is mentioned in the law. A second issue is the weights that are assigned to each question. These weights are supposed to reflect the importance of each question. We think that these weights should be chosen by the users of the database depending on their use. Nevertheless, given the high number of questions (more than 130 questions for economic migration), this might be a difficult task.

Finally, a tricky problem relates to the treatment of the missing information and of the zeroes. To illustrate this point, suppose that we have a set of three questions applicable to a set of three entry tracks, each of which captures conditions of entry for high skilled workers in a given country. The three questions relate to whether education is taken into account, whether professional experience is taken into account, and whether language skills of prospective migrants are evaluated. Suppose that for Country A, the law is very clear and explicit, that for country $\mathrm{B}$, it is unclear with respect to the last two questions, and that for country $\mathrm{C}$ it is unclear regarding linguistic skills only. For each question, 1 indicates a positive answer, 0 a negative answer. This situation is summarized in Table 4. The last two rows of Table 4 capture the final outcome of the aggregate index under two different aggregation schemes. In the last row but one, we assume that if nothing is mentioned in the law, this is equivalent to an explicit statement that the law does not impose this requirement. In the last row, we assume in contrast that the condition is ambiguous and the computation of the aggregate index does not include this question. A comparison of the two cases suggests that the treatment of ambiguity is of primary importance: in the first case, the most ambiguous country is considered the least 
selective while in the other case, it appears as the most selective. This illustrates the importance of the choice of treatment of ambiguous information in the law.

The implication of this is that we need to make an explicit distinction between cases in which the immigration law implies a clear negative answer and cases in which there is no explicit answer. Therefore, the raw data will include some qualitative information associated to negative answers, with detailed information about the sources in the law and/or the origin of the coding. It is then up to the final user to make the final coding of ambiguous answers and to decide whether he/she will include those specific questions. Furthermore, the pilot phase should identify the set of particular questions that are associated with ambiguous answers for a majority of countries. This could suggest a change in the exact wording of these questions, or even that these questions should be deleted.

\subsection{Aggregation of tracks}

We now turn to the aggregation of entry tracks. All entry tracks are of course not of similar importance. This creates two separate issues. First, several countries have 'exotic' entry tracks that concern very few people. Furthermore, there are idiosyncratic entry tracks in that they are found only in a single country. A striking example of such an entry track is the visa for crews on super-yachts in Australia that was introduced in 2008. This limits the comparability across countries. In turn this raises the issue of whether these 'exotic' tracks should be kept in the aggregation process.

The second issue concerns the importance of the entry tracks and the weighting scheme that we want to use. Suppose that we want to build an index concerning the selectivity of immigration policy on education requirements and that we select one question related to the education level needed to be admitted. One possible way of weighting entry tracks would be to use the proportion of migrants entering the country in each of our track the year before. This might be problematic, however, for two reasons. First, this type of data might be 
unavailable in a lot of cases. Annual flows of migrants are difficult to find even at the aggregate level. The availability of annual flows of immigrants broken down by entry track might be more the exception than the rule. ${ }^{28}$ Second, the proportion of immigrants in each entry track is obviously endogenous. In particular, they will depend on the requirements and the restrictions that the immigration authorities impose on prospective migrants. This will in turn lead to biases in the aggregated indexes.

Table 4: Aggregation of questions in presence of uncertainty

\begin{tabular}{|l|l|l|l|}
\hline Criteria & Country A & Country B & Country C \\
\hline Number of education years or degree & 1 & 1 & 1 \\
\hline Professional experience & 1 & $\mathrm{n} / \mathrm{a}$ & 0 \\
\hline Language skills & 0 & $\mathrm{n} / \mathrm{a}$ & $\mathrm{n} / \mathrm{a}$ \\
\hline Index (n/a treated as 0) & $2 / 3$ & $1 / 3$ & $1 / 3$ \\
\hline Index (forget n/a) & $2 / 3$ & 1 & $1 / 2$ \\
\hline
\end{tabular}

\section{Conclusion}

The IMPALA project aims at building a new database capturing immigration policies applied to various types of prospective migrants in some of the major immigration countries. The project emphasizes the need to yield comparable data across countries and over time, recognizing and trying to address the difficulties inherent to defining a methodology applicable to all countries while at the same time able to capture the differences in the policies conducted. After careful work on the methodological aspects, the research consortium of the IMPALA project has started to apply these methodologies to a set of pilot countries for the most recent period.

\footnotetext{
${ }^{28}$ An alternative approach would be to estimate for each entry track the number of potential migrants from the rest of the world. However, such an estimation might be possible only in the case of very specific entry tracks (e.g., for sportsmen or scientists).
} 
This paper provides an overview of the IMPALA project and illustrates the progress that has been made with some data pertaining mostly to policies governing economic migration. The key idea of the IMPALA project is to code policies from the immigration laws prevailing in each country. The most important concept underlying the IMPALA approach is the concept of entry track which defines one particular way for a migrant to be admitted in the country. The paper gives early estimates of the number of entry tracks for economic migrants in six pilot countries over the period 1990-2008. The data illustrate the significant degree of heterogeneity in the number of entry tracks across countries.

Each identified entry track in each category of migration is subject to a set of questions that allows for capturing the conditions of admission for that particular entry track. This means that the basic unit of observation in the IMPALA database integrates several dimensions: country, year, category, entry track, and question. In turn, this raises a number of issues as to how these observations can be aggregated to yield meaningful indices of stringency in immigration policies. The paper discusses several of these issues. One issue relates to how we might code when there is an uncertainty in the law concerning some particular aspects of the policy.

In addition to the coding of immigration policies in the different categories, the IMPALA project has also developed a methodology to capture bilateral migration policies. These bilateral policies are variations of the policies specific to a particular migration corridor. Their coding is important for several reasons. One is that it is a natural complement to the immigration policies captured in the various categories. Another reason is that it allows for measuring whether and to what extent some immigration countries discriminate across migrants of different origins. 


\section{References}

Alesina, A., J. Harnoss and H. Rapoport (2014): Immigration and attitudes to redistribution: a view from Europe, Mimeo., Harvard University.

Artuc, E., F. Docquier, C. Ozden and C. Parsons (2015): A Global Assessment of Human Capital Mobility: the Role of non-OECD Destinations, World Development, 65: 6-26.

Bauer, T., M. Lofstrom and K. Zimmerman (2000):Immigration Policy, Assimilation of Immigrants and Natives Sentiments Towards Immigrants: Evidence from 12 OECD Countries.Swedish Economy Policy7, 2, 11-53.

Beine, M., F. Docquier and C.Ozden (2011a): Diasporas, Journal of Development Economics, 95, 1: 3041.

Beine, Michel, Frederic Docquier and CaglarOzden (2011b): Dissecting network externalities in international migration, CES Ifo Working Paper, 3333, Munich.

Beine, M. and C. Parsons (2012): Climatic factors as determinants of international migration, CES Ifo Working Paper, 3747, Munich.

Beine, M., B. Burgoon, M. Crock, J. Gest, M.Hiscox, P. McGovern, H. Rapoport, J. Schaperand E.Thielemann. (2015), Comparing Immigration Policies: An Overview from the IMPALA Database. Forthcoming in International Migration Review.

Beine, M. and S.Salomone (2013c): Network effect in international migration: does education matter more than gender?, Scandinavian Journal of Economics, 115(2), 354-80.

Beine, M., F. Docquier and H. Rapoport (2007), Measuring International Skilled Migration: New Estimates Controlling for Age of Entry.World Bank Economic Review 21 (2): 249-54.

Bélot, M. and S. Ederveen (2012), Cultural Barriers in Migration in OECD Countries., Journal of Population Economics, 25 (3): 1077-1105.

Bertoli, S. and H. Rapoport (2015): Heaven's swing door: endogenous skills, migration networks and the effectiveness of quality-selective immigration policies, forthcoming in Scandinavian Journal of Economics.

Bertoli, S., and J. Fernandez-Huertas Moraga (2013): Multilateral resistance to migration, Journal of Development Economics, 102, 79-100.

Boeri, T., Hanson, G., and McCormick, B. (2002),Immigration Policy and the Welfare System. Oxford: Oxford University Press.

Borjas, G. (1999),Heaven's Door: Immigration Policy and the American Economy. Princeton: Princeton University Press.

Bosniak, Linda. (2006), The Citizen and the Alien: Dilemmas of Contemporary Membership. Princeton: University Press.

Boucher, Anna and Justin Gest (2013),Migration Studies at a Crossroads: A Constructive Critique of Migration and Integration Regime Typologies, working paper under review.

Brochmann, G. and T. Hammar, ed. (1999),Controlling Immigration in Europe: Mechanisms of Immigration Control: A Comparative Analysis of European Regulation Policies. Oxford: Berg.

Brücker, H., S. Bertoli, AM. Mayda and G. Peri(2012), Understanding Highly Skilled Migration in Developed Countries: The Upcoming Battle of Brains: in: Brain Drain and Brain Gain-the Global Competition to Attract High-Skilled Migrants, edited by T. Boeri, H. Brücker, F. Docquier and H. Rapoport, Oxford, Oxford University Press.

Burgoon, Brian. (2014), Immigration, Integration and Support for Redistribution in Europe.”World Politics 66 (3). 
Burgoon, B. and D. Raess. (2011), Does the Global Economy Mean More Sweat?: Trade, Investment, Migration and Working Hours in Europe."Socio-Economic Review 9(4): 699-727.

Burns, P., and J. Gimpel. (2000), Economic Insecurity, Prejudicial Stereotypes, and Public Opinion on Immigration Policy.” Political Science Quarterly 115 (3): 201-225.

Centraal Bureau Statistiek (CBS). CBS (2012), Arbeidsmigratie Belangrijkste Migratiestroom. http://www.cbs.nl/nl-NL/menu/themas/bevolking/publicaties/artikelen/archief/2012/2012migratiekaart-art.htm (accessed on November 6, 2012)

Cerna, L. (2008), Towards an EU Blue Card? The Delegation of National Highly Skilled Immigration Policies to the EU level" In: Towards an EU Blue Card? The delegation of National Highly Skilled Immigration Policies to the EU level. Oxford: Oxford University, Centre on Migration, Policy and Society (COMPAS).

Challen, S.(2014),Measuring Change in Immigration Policy. El Paso: LFB Scholarly Publishing LLC.

Chandler, C., and Y. Tsai. (2001), Social Factors Influencing Immigration Attitudes: An Analysis of Data from the General Social Survey.The Social Science Journal, 38 (2): 177-188.

Citrin, J., D. Green, C. Muste, and C. Wong. (1997), Public Opinion Toward Immigration Reform: The Role of Economic Motivations."Journal of Politics 59 (3): 858-81.

Cornelius, W. et al. (eds). (2004), Controlling Immigration: A Global Perspective. Stanford: Stanford University Press.

Coppedge, M., J. Gerring, D. Altman, M. Bernhard, S. Fish, A. Hicken, M. Kroenig, S.I. Lindberg, K. McMann, P. Paxton, H.A. Semetko, S.E. Skaaning, J. Staton, and J. Teorell (2011), Conceptualizaing and Measuring Democracy: A New Approach."Perspectives on Politics 9 (2):247-268.

Crock, M. (Ed.). (1993),Protection Or Punishment? The Detention of Asylum-seekers in Australia. Sydney: Federation Press.

Crock, M. (2007), Defining Strangers: Human Rights, Immigrants and the Foundations of a Just Society." 31 Melbourne University Law Review 1053.

Czaika, M. (2009), A Refugee Burden Index: Methodology and its Application."Migration Letters 2 (2):101-15.

Dauvergne, C. (2007), Security and Migration Law in the Less Brave New World"Social and Legal Studies 16(3): 533-549.

Docquier, F., Machado, J. and Sekkat K. (2015), Efficiency gains from liberalizing labor mobility, Scandinavian Journal of Economics, forthcoming.

Docquier, F. and A. Marfouk (2006), International Migration by Educational Attainment (1990-2000)", in C. Ozden and M. Schiff (Eds), International Migration, Remittances and Development, Palgrave MacMillan: New York.

Docquier, F., H. Rapoport and S. Salomone (2012), "Remittances, migrants' education and immigration policy: theory and evidence from new bilateral data", Regional Science and Urban Economics, 42, 5: 817-28

Dustmann, C. and Preston, I. P. (2007), Racial and Economic Factors in Attitudes to Immigration."The B.E. Journal of Economic Analysis \& Policy 7(1).

EUDO [European Union Democracy Observatory on Citizenship] (2011). http://eudo-citizenship.eu/.]

Espenshade, T., and C. Calhoun. (1993), An Analysis of Public Opinion toward Undocumented Immigration."Population Research and Policy Review 12: 189-224.

Euraxess(2010), The Blue Card: Your Entry Pass to the European Labor Market? http://www.euraxess.nl/newsletter/archive/june-2011/the-blue-card-your-entry-pass-to-the-europeanlabour-market/?searchterm (accessed on Nov.15, 2012) 
European Migration Network (EMN) (2010), EMN Studie - Inzet Migratie op de Nederlandse Arbeidsmarkt. Rijswijk: EMN

Everaert (2012), New Rules on Family Reunification from 1st of July.http://www.everaert.nl/en/news/16particulieren/119-nieuwe-regels-gezinsmigratie-per-1-juli (accessed on Nov. 15, 2012).

Facchini, G. and A.-M. Mayda (2009), Does the Welfare State Affect Individual Attitudes towards Immigrants? Evidence Across Countries. Review of Economics and Statistics, 91, 2: 295-314.

Fetzer, J. (2000),Public Attitudes toward Immigration in the United States, France, and Germany. Cambridge: Cambridge University Press.

Freeman, G. (1979), Immigrant Labor and Racial Conflict in Industrial Societies. Princeton, NJ: Princeton Univ. Press.

Gest, J., A. Boucher, S. Challen, B. Burgoon, E. Thielemann, M. Beine, P. McGovern, M. Crock, H. Rapoport and M. Hiscox (2014), Measuring and Comparing Immigration, Asylum and Naturalization Policies Across Countries: Challenges and Solutions, Global Policy, 5, 3: 261-274.

Givens, T. and Luedtke, A. (2004), The Politics of European Union Immigration Policy: Institutions, Salience and Harmonization. Policy Studies Journal 32(1) 145-65.

Grogger, J. and G. Hanson. (2011), Income Maximization and the Selection and Sorting of International Migrants. Journal of Development Economics 95, 1: 42-57.

Hainmueller, J. and M.Hiscox. (2010), Attitudes Towards Highly Skilled and Low Skilled Immigration: Evidence from a Survey Experiment."American Political Science Review 104(1): 1-24.

Hammar, T. (1985), European Immigration Policy: A Comparative Study. Cambridge, UK: Cambridge University Press.

Hanson, G., Scheve, K. and Slaughter, M. (2007), Public Finance and Individual Preferences over Globalization Strategies. Economics and Politics 19(1).

Harnosss, J. (2014): Birthplace diversity and attitudes to immigration, Mimeo., University Paris 1 Pantheon-Sorbonne.

Hatton, T. J. (2004), Seeking Asylum in Europe. Economic Policy, 19(38), 5-62.

Heath, A. F. (2007), Cross National Patterns and Processes of Ethnic Disadvantage in Heath, A. F. and Cheung, S. Y. Unequal Chances: Ethnic Minorities in Western Labour Markets, Oxford, published for the British Academy by Oxford University Press.

Heath, A. F. and Cheung, S. Y. (2007),Unequal Chances: Ethnic Minorities in Western Labour Markets, Oxford, published for the British Academy by Oxford University Press.

Helbling, M. (2008), Practicing Citizenship and Heterogeneous Nationhood. Naturalizations in Swiss Municipalities. Amsterdam: Amsterdam University Press.

Howard, M.M. (2005), Variation in Dual Citizenship Politics in the Countries of the EU.International Migration Review 39 (3):697-720.

Howard, M.M. (2006), Comparative Citizenship: An Agenda for Cross-National Research. Perspectives on Politics 4 (3):443-455.

Howard, M.M. (2009). The Politics of Citizenship in Europe. Cambridge:Cambridge University Press.

Huntington, Samuel P. (2004). Who Are We? New York: Simon \& Schuster.

Joppke, C. (1999), Immigration and the Nation-State. Oxford: Oxford University Press.

Janoski, T. (2010), The Irony of Citizenship: Naturalization and Integration in Industrialized Countries. Cambridge: Cambridge University Press.

Kitschelt, Herbert. (1995), The Radical Right in Western Europe. Ann Arbor: The University of Michigan Press. 
Kogan, I. (2007), Working Through Barriers: Host Country Institutions and Immigrant Labour Market Performance in Europe. Dordrecht: Springer.

Koopmans, R., I. Michalowski, and S. Waibel. (2012), Naturalization Rights for Immigrants: National Political Processes and Cross-National Convergence in Western Europe, 1980-2008. American Journal of Sociology, 117 (4): 1202-1245.

Koopmans, R., I. Michalowski, and S. Waibel. (2010), Citizenship Rights for Immigrations: National Paths and Cross-National Convergence in Western Europe, 1980-2008. In WZB Discussion Paper SP IV, 2010-703. Berlin: Social Science Research Centre Berlin.

Koopmans, R., P. Statham, M. Giugni, and F. Passy. (2005), Contested Citizenship: Immigration and Cultural Diversity in Europe, Minneapolis and London: University of Minnesota Press.

Lowell, L. (2005), Policies and Regulations for Managing Skilled International Migration for Work In: Policies and Regulations for Managing Skilled International Migration for Work. New York: United Nations, Mortality and Migration Section of the Population Division.

Mayda, A.-M. (2006), Who is Against Immigration? Review of Economics and Statistics, 88(3).

Mayda, A.-M. (2010), International Migration: A Panel Data Analysis of the Determinants of Bilateral Flows. Journal of Population Economics, 23 (4): 1249-1274.

McGovern, P. (2013), Inequalities in the (De-)Commodification of Labour: Immigration, the Nation State, and Labour Market Stratification. Sociology Compass, 6 (6): 485-498.

McKenzie, D. and H. Rapoport (2007): Network effects and the dynamics of migration and inequality: theory and evidence from Mexico, Journal of Development Economics, 84, 1: 1-27.

McKenzie, D. and H. Rapoport (2010): Self-selection patterns in Mexico-US migration: the role of migration networks, Review of Economics and Statistics, 92, 4: 811-21.

McLaren, L. (2001), Immigration and the New Politics of Inclusion and Exclusion in the European Union." European Journal of Political Research, 39: 81-108.

Massey, D. (1999), "International Migration at the Dawn of the Twenty-first century: The Role of the State," Population and Development Review, 25, 2: 303-322.

Meyers, E. (2004),International Immigration Policy: A Theoretical and Comparative Analysis.New York: Palgrave Macmillan,

MIPEX (2011), How does MIPEX decide the scores? Retrieved March 2012 <http://www.mipex.eu/methodology>.

Morissens, A. and Sainsbury, D.(2005), Migrants' Social Rights, Ethnicity and Welfare Regimes, Journal of Social Policy 34 (4): 637-60.

Neumayer, E. (2004), Asylum Destination Choice: What Makes Some West European Countries More Attractive than Others? European Union Politics 5 (2):155-180.

Niessen, J., Huddleston, T., Citron, L., Geddes, A., and Jacobs, D.(2007), Migrant Integration Policy Index. British Council and Migration Policy Group: Brussels. Available Online: http://www.integrationindex.eu/

OECD (2004): Migration et emploi: les accords bilatéraux à la croisée des chemins, Paris : OECD Editions.

Olzak, S. (1992), The Dynamics of Ethnic Competition. Stanford, CA: Stanford University Press.

Ortega, F., and G. Peri (2009), The Causes and Effects of International Migrations: Evidence from OECD Countries 1980-2005."NBER Working Paper No. 14883.

Putnam, Robert. (2007), E Pluribus Unum: Diversity and Community in the Twenty-first Century, The 2006 Johan Skytte Prize Lecture. Scandinavian Political Studies 30 (2): 137-74.

Razin, A., E. Sadka and B. Suwankiri (2011): Migration and the Welfare State, MIT Press. 
Rubenstein, K. (2002), Citizenship, Sovereignty and Migration: Australia's Exclusive Approach to Membership of the Community, 13 Public Law Review 102.

Ruhs, M. (2011), Openness, Skills and Rights: An Empirical Analysis of Labour Immigration Programmes in 46 High and Middle Income Countries. Oxford University, Centre on Migration, Policy and Society (COMPAS) Working Paper Series, July 2011.

Ruhs, Martin and Martin, Philip. (2008), Numbers vs. Rights: Trade-Offs and Guest Worker Programs. International Migration Review 42 (1), 249-65.

Sainsbury, Diane. (2006), Immigrant's Social Rights in Comparative Perspective: Welfare Regimes, Forms of Immigration and Immigration Policy Regimes.Journal of European Social Policy 16 (3), 229-44.

Scheve, K., and M. Slaughter (2001), Labor Market Competition and Individual Preferences over Immigration Policy. Review of Economics and Statistics 83 (1): 133-145.

Smith, M. P. and Favell, A. (2006), The Human Face of Global Mobility: International Highly Skilled Migration in Europe, North America and the Asia-Pacific.

Thielemann E. R. (ed.) (2003), European Burden-Sharing and Forced Migration. special issue of the Journal of Refugee Studies 16(3).

Thielemann, E. R. (2004), Why European Policy Harmonization Undermines Refugee Burden-sharing. European Journal of Migration and Law, 6(1): 43-61.

Thielemann, E.R. (2006), The Effectiveness of Asylum Policy in Controlling Unwanted Migration, in Parsons C. and Smeeding T. (eds.) Immigration and the Transformation of Europe, Cambridge: Cambridge University Press: 442-72.

Timmer, A. S., and Williamson, J. G. (1996), Racism, Xenophobia or Markets? The Political Economy of Immigration Policy Prior to the Thirties. NBER Working Paper No. W5867.

Timmer, A. S., and Williamson, J. G. (1998), Immigration Policy Prior to the 1930s: Labor Markets, Policy Interactions, and Globalization Backlash. Population and Development Review, 24(4), 739742.

Waldrauch, H., and C. Hofinger. (1997), An Index to Measure the Legal Obstacles to the Integration of Migrants. New Community 23 (2):271-285.

Watts, J. R. (2002), Immigration Policy and the Challenge of Globalization: Unions and Employers in Unlikely Alliance. Cornell University Press. 